DOI: $10.2478 / \mathrm{v} 10025-010-0022-9$

JOURNAL OF WATER

AND LAND DEVELOPMENT

J. Water Land Dev. No. 13a, 2009: 103-113

\title{
An analysis of tree stand stability relative to Institute of Meteorology and Water Management (IMGW) classification of maximum wind velocities
}

\author{
Tomasz KALUŻA ${ }^{1)}$, Jacek LEŚN $Y^{2}$ \\ 1) University of Life Sciences Poznań, Department of Hydraulic Engineering, Piątkowska 94, 60-649 \\ Poznań, Poland; e-mail: kaltom@gmx.net \\ ${ }^{2)}$ University of Life Sciences Poznań, Agrometeorology Department, Piątkowska 94, 60-649 Poznań, \\ Poland; e-mail: jlesny@au.poznan.pl
}

\begin{abstract}
Analysing tree susceptibility to uprooting one has to compare external power acting on a tree with its resistance to uprooting (critical moment). The critical uprooting moment for a tree depends on both plant parameters and substratum. Results of an assessment of critical moments of studied pine and black alder tree stands are presented in this paper. Field studies consisted of uprooting trees with parallel measurements of critical moments. Results were compared with the moments of uprooting power of extreme winds. These moments were related to classification of maximum wind velocities proposed by the Institute of Meteorology and Water Management (IMGW).
\end{abstract}

Key words: strong winds, uprooting moments of trees

\section{INTRODUCTION}

Many extreme meteorological phenomena take place in the territory of Poland and worldwide. One of such phenomena is strong winds which cause various types of damage and losses. Most numerous are the destructions of tree stands. Under such conditions tree branches are often being broken and whole trees uprooted. The latter effect is enhanced when trees grow on light non-compact soils or in soil saturated with water. The effect of extremely strong wind depends on the shape and surface area of an affected object. Natural surfaces of trees and herbs cope better with even very strong winds. To estimate the range of wind velocities that might pose a risk it has been assumed that maximum wind velocity is that which under Polish conditions results in material losses and, under exceptionally unfavourable circumstances, may cause casualties. 


\section{CLASSIFICATION OF STRONG WINDS}

Since the effects of wind action depend on its velocity, IMGW (LORENC, 2008) proposed a special scale to estimate the size of damage in relation to wind velocity. Lower limit of this scale is the velocity of $17.2 \mathrm{~m} \cdot \mathrm{s}^{-1}$. The rationale for adopting this limit arose from criteria based on Beaufort scale and scales estimating wind velocity and damage at the same time. Table 1 presents proposed division of winds into classes according to their velocity and force. Class V involves three additional sub-classes for winds exceeding $32.7 \mathrm{~m} \cdot \mathrm{s}^{-1}$ whose destructive force could produce inconceivable disaster. For example, the wind that blew in the Slovak Tatras on $19^{\text {th }}$ November 2004 acc. to meteorological records had a velocity of 170 $\mathrm{km} \cdot \mathrm{h}^{-1}$. It wreaked havoc on the Tatra tree stand and destroyed infrastructure and buildings. Two persons died of this gale (GIL, 2005).

Table 1. Classification of the dangerous maximum wind velocities and their effects (LORENC, 2008)

\begin{tabular}{|c|c|c|c|}
\hline Class & $\begin{array}{l}\text { Wind velocity } \\
\mathrm{m} \cdot \mathrm{s}^{-1}\end{array}$ & Wind characteristic & Effects \\
\hline $\mathrm{I}$ & $17.2-20.7$ & near gale & $\begin{array}{l}\text { wind breaks tree branches, walking against } \\
\text { wind is difficult }\end{array}$ \\
\hline II & $20.8-24.4$ & gale & $\begin{array}{l}\text { wind makes damage to buildings, blows off } \\
\text { roof tiles, breaks whole trees }\end{array}$ \\
\hline III & $24.5-28.4$ & strong gale & $\begin{array}{l}\text { wind uproots trees, causes large building de- } \\
\text { structions (blowing off the roofs, breaking tow- } \\
\text { ers and energetic piles) }\end{array}$ \\
\hline IV & $28.5-32.6$ & storm & wind produces large destruction, life at risk \\
\hline V & $\geq 32.7$ & hurricane or whirlwind & large destruction and havoc, possible fatalities \\
\hline $\mathrm{V}-1$ & $35.1-50.1$ & strong & \\
\hline $\mathrm{V}-2$ & $50.2-70.2$ & destructive & \\
\hline $\mathrm{V}-3$ & $\geq 70.3$ & devastating & \\
\hline
\end{tabular}

The problem with using table 1 is that it is more difficult to predict consequences of a given wind velocity on land than at the sea. Whether a tree will be broken or uprooted under the wind force depends on many factors like: tree species, type and moisture of the substratum, season etc. Proposed classification (either by IMGW or directly the Beaufort scale) is thus an average of phenomena that may possibly happen. Such classifications are, however, necessary for weather forecasts and for sending gale warnings. 


\section{EXTERNAL MOMENT DUE TO WIND}

Considering a possibility of the tree overturn one has to compare external force acting upon tree with its resistance to overturn - the critical moment (HARTGE, 1993):

$$
\frac{M_{c}}{M_{W}} \geq 1
$$

where:

$M_{c}$ - critical moment,

$M_{W}$ - external moment due to wind.

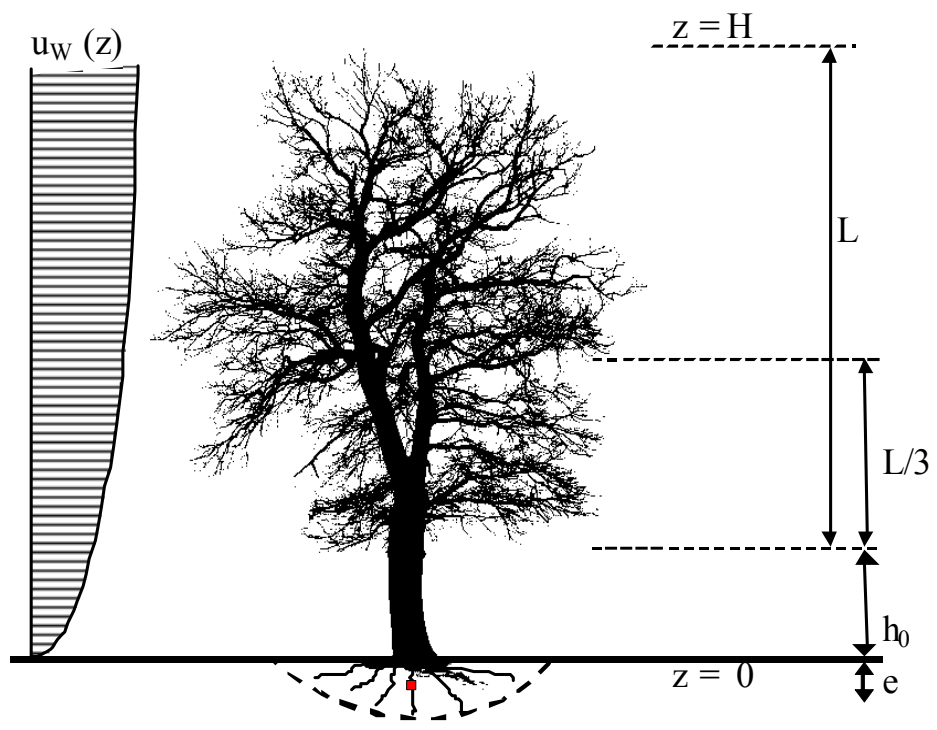

Fig. 1. Dynamic pressure of wind acting upon a tree

Wind induced overturn moment of forces acting upon a tree (Fig. 1), at the assumption of constant wind velocity and constant drag coefficient, may be presented in a form of the equation:

$$
M_{W}=\frac{1}{2} \rho_{P} C_{K} u_{W}^{2} S\left(e+h_{o}+\frac{L}{3}\right)
$$

where:

$\rho_{P}-$ air density,

$C_{K}$ - drag force coefficient of the tree, 


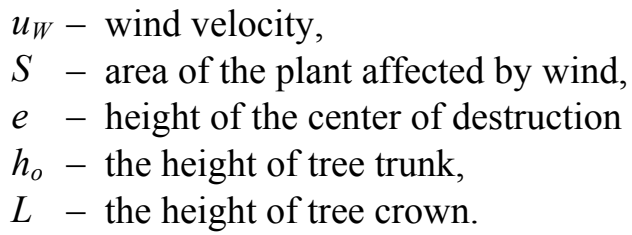

To determine wind induced overturn moment one needs to know the parameters of tree structure: the diameter of tree trunk and surface area of a tree. The latter is a projection of tree crown on a vertical plane.

Resistance to overturn depends on the root system of a plant which is speciesspecific and depends on the type of soil (KAŁUŻA and WIERZBICKI, 2006). Critical moment of the tree uprooting was described in the literature (Proposed guidelines..., 1994) by empirical equation:

$$
M_{c}=\alpha D^{a}
$$

where:

$a$ - empirical constant,

$D$ - diameter at breast height $(1.2 \mathrm{~m})$,

$\alpha$ - empirical constant.

Constants $\alpha$ and $a$ may be estimated experimentally. To do this selected trees have to be of the same species for which critical moment had been measured. Moreover, all trees should grow in similar conditions and have various diameters at breast height. Then, constants $\alpha$ and a may be determined with statistical methods e.g. with the least square method.

\section{FIELD MEASUREMENTS OF THE CRITICAL MOMENT}

Estimation of the critical moment in the field consisted in measurement of the force needed to uproot the tree. Force measurement was made with a dynamometer based on force sensor CL 15 in the range up to $200 \mathrm{kN}$ made by the Company of Electronic Mesurements of Non-electric Values in Marki. Measurement system included processing system CL 10, analogue-digital chart and a notebook with special programme to follow and record the results. Coupling dynamometer with computer enabled precise recording of increasing force until uprooting the tree. The source of uprooting force was a heavy caterpillar used in forest cutting and road works (Fig. 2).

The height of a girding cable 1 enlarged by the depth of a hollow e formed arm of the force that served to estimate critical moment $M_{c}$ (Fig. 2): 


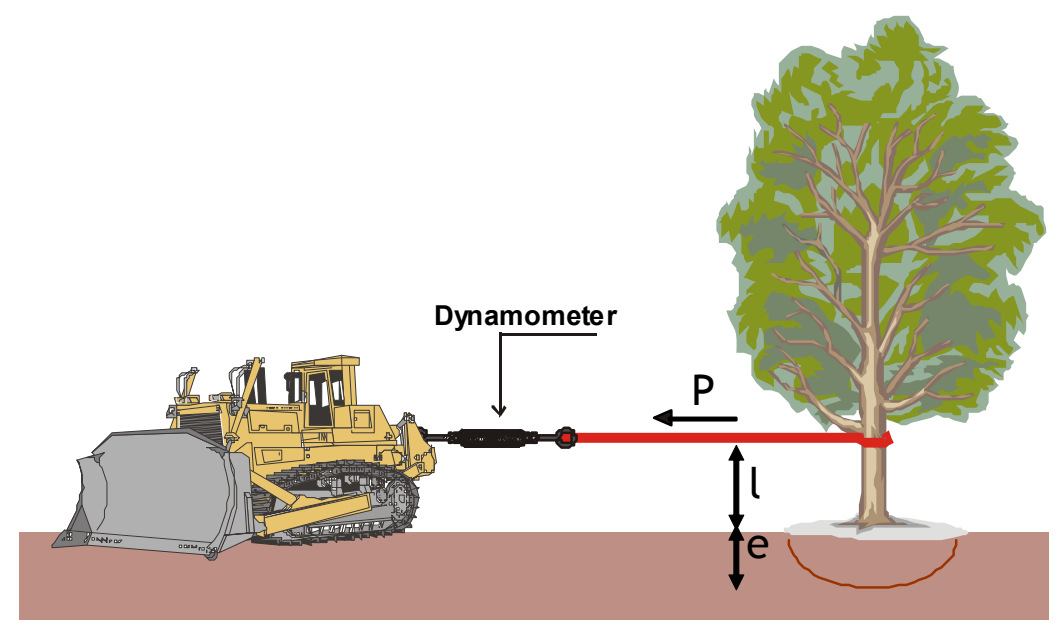

Fig. 2. Schematic view of performed measurements

$$
M_{c}=(l+e) P
$$

where:

$l+e \quad-$ arm of a force i.e. the height of cable attachment measured from the bottom of the root-soil plate,

$P \quad-$ maximum force needed to uproot the tree.

Determination of the critical moment required estimation of the maximum force needed to overturn the tree at a given height of force application. Force $\mathrm{P}$ at which the tree irreversibly lost its stability was recorded during measurements. Coupling of dynamometer with computer allowed for precise noticing the increase of applied force until uprooting the tree (Fig. 3). Maximum force noted from the course of measurements was adopted as appropriate.

An assessment of the critical overturn moment was performed in two experimental objects. The first was localised in the floodplain of the Warta River in Częstochowa between $739+065 \mathrm{~km}$ and $740+260 \mathrm{~km}$ of the river course. Both right and left bank of the $1200 \mathrm{~m}$ long river stretch were overgrown by dense woodlots of the black alder (Alnus glutinosa) with the admixture of the ash-leaved maple (Acer negundo) and white willow (Salix alba). Only black alder trees were used for measurements - 30 trees on the left river bank and 12 trees on the right one. Diameter at breast height of these trees varied from 7 to $43 \mathrm{~cm}$. Tree height ranged from 6 to $16 \mathrm{~m}$. The second study object was situated at the edge of the Sama River valley near Obrzycko in wielkopolskie voivodship. Measurements of the Scots pine (Pinus sylvestris L.) were made in two forest divisions in the Forst Superintendency Oborniki, Forest District Żurawiniec, divisions 1072d and 1095b. The forests differ in age and hence in the height and diameter of tree trunks and in tree 


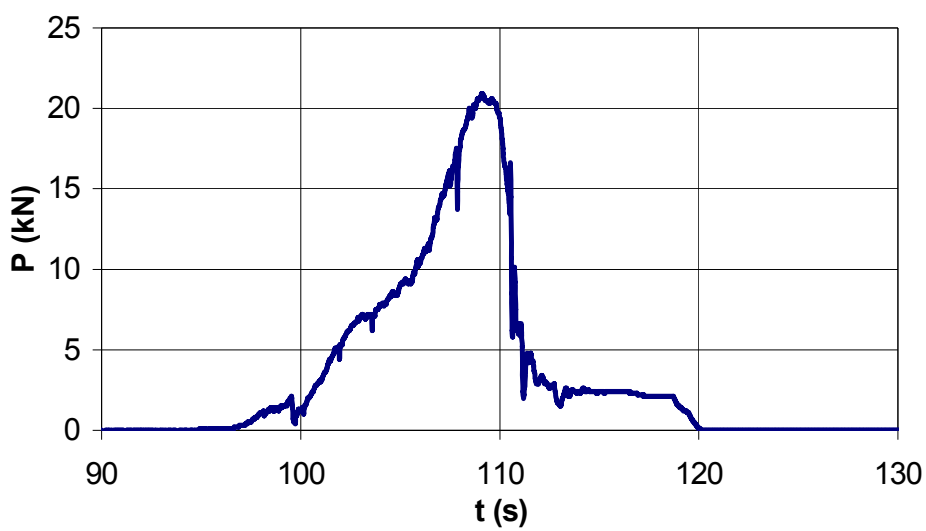

Fig. 3. The course of uprooting black alder tree D10, the Warta River valley, Częstochowa

density. Diameter at breast height of analysed trees varied from 12 to $43 \mathrm{~cm}$ and their height - from 15 to $30 \mathrm{~m}$.

After uprooting trees their diameter at breast height, total length, the length of a trunk, crown width, the width of root-soil plate and the depth of hollow were measured. In the hollow, from under roots, soil samples for further analyses were taken. Soil geotechnical parameters were estimated in the close vicinity of overturned trees. Hand drilling, tests with dynamic sound and penetrometer pressed statically to the depth of $2 \mathrm{~m}$ below ground were made in every sampling point. Drilling enabled assessment of the lithologic profile while estimation of basic geotechnical parameters was based on the results of sounding. Laboratory analyses of soil samples included grain size structure and moisture content of studied soils. Data from the Warta River valley in Częstochowa showed that subsurface soil layer along the studied river stretch were composed of embankment materials made of moderately humic sands with the admixture of rubble and stones. Embankments were loosely to moderately compact. Substratum in the second study object at the edge of the Sama River valley had more uniform structure. Soils were almost exclusively composed of medium and fine sands with the admixture of gravel and represented typical alluvial deposits. Soil profiles were almost identical in the whole area. Upper soil layer with humus admixtures was moderately compact to the depth of 1.4-1.5 $\mathrm{m}$ from where it turned out to compact status.

Results of performed experiments confirmed strong relationship between critical moments and the diameter at breast height of analysed trees (Figs 4 and 5). Constants $\alpha$ and a were calculated with the statistical least square method. Obtained correlation coefficients ( $R=0.926$ for pine and $R=0.869$ for alder tree) indicate good approximation of obtained results by the diameter at breast height. 


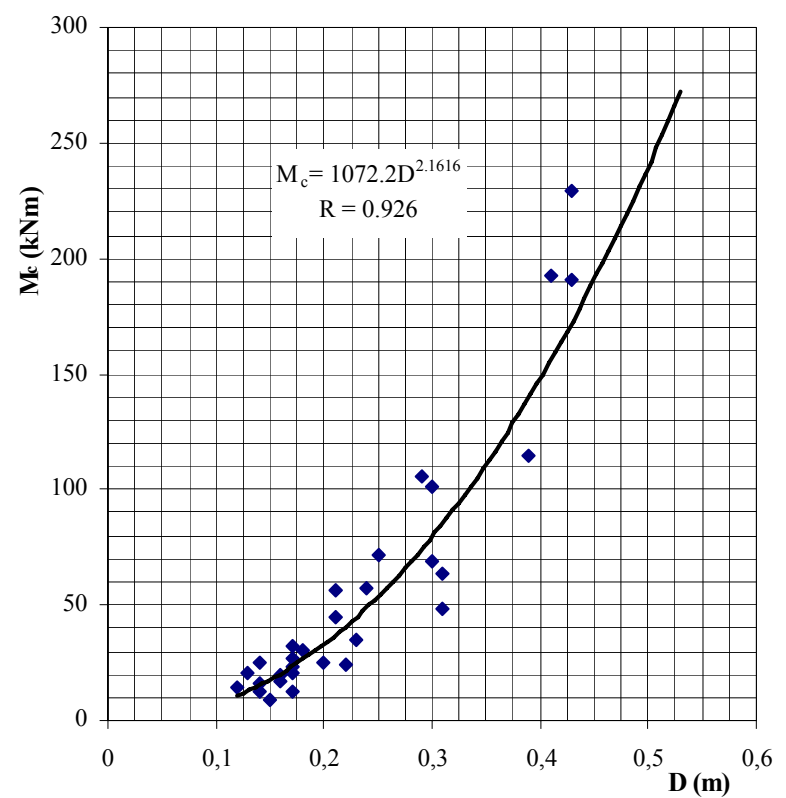

Fig. 4. The relationship between critical overturn moment $M_{c}$ and diameter at breast height $D$ for pine trees

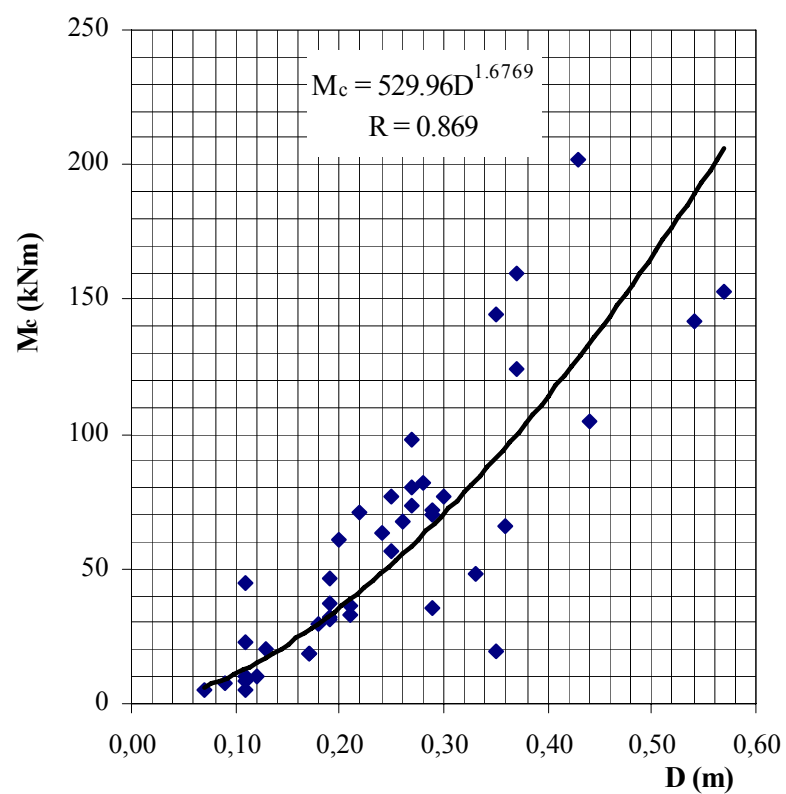

Fig. 5. The relationship between critical overturn moment $M_{c}$ and diameter at breast height $D$ for alder trees 
Field studies included also measurements of leaf area and density indices (LAI and LAD) with the use of LAI-2000 meter. LAI measurements on a small densely overgrown area assumed plant layer homogeneity. Knowing the number of trees on study area and surface area of the projection of tree crowns on horizontal surface it was possible to estimate mean cross-section areas of all twigs, branches and tree trunk of an average tree. LAI was measured by exposing the sensor $1 \mathrm{~m}$ above ground to avoid interference from grasses and other annual plants. Therefore, obtained results should respectively be enlarged by tree trunk surfaces not considered in these measurements.

\section{IMGW CLASSIFICATION OF OVERTURNING WIND VELOCITIES AND REAL DAMAGE IN A TREE STAND}

The wind velocities that would uproot particular trees were estimated from measured values of the overturn moments and geometric parameters of uprooted trees using transformed equation (2). An important issue was to estimate the area exposed to wind action. This is obvious for tree trunk but in the case of tree crown its openwork spatial structure should be considered. Crown area was in this study determined from its projection on vertical plane. Then, the value was verified based on measured LAI which represented total, one-sided area of leaves (needles) and branches within the tree crown.

In further analyses wind velocities were referred to classes of maximum wind velocity proposed by IMGW. Fig. 6 shows the distribution of wind velocities for pine trees. Performed studies demonstrated that already near gale winds may cause relatively large damage to pine tree stands. Among 29 uprooted trees only three fell below class I, most trees would have been overturned if the wind had achieved II class of wind velocity and only three would have survived the V class. Noteworthy, the study was performed in dense pine tree stands in which trees rarely encounter so high wind velocities. Pine trees growing in open areas have more developed root system and are hence more resistant to overturning by strong winds.

Figure 7 presents the distribution of uprooted black alder trees among particular ranges of wind velocity and classes proposed by IMGW. In total 42 alder trees were uprooted, 8 of them fell below class I. So low resistance of these trees to wind force resulted rather from the character of soil they grew in. It should be underlined here, that substratum in river valleys is quite heterogeneous and often very moist which might be the reason why some trees growing there might be overturned even at low wind velocities. Half of studied trees would have been uprooted by winds from classes II to V. Six trees appeared very resistant to wind above $50.1 \mathrm{~m} \cdot \mathrm{s}^{-1}$ i.e. the winds from class V-2. 


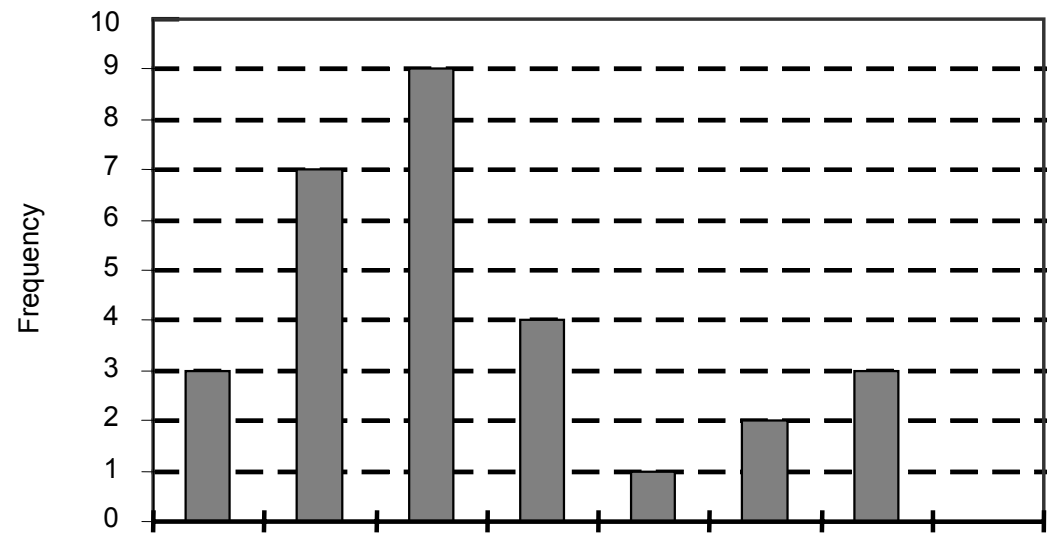
Wind, $\mathrm{m} \cdot \mathrm{s}^{-1}$
17.2
20.7
24.4
$28.5 \quad 32.6$
35.1
50.1
Scale IMGW
II
III
IV
$\mathrm{V}-1$

Fig. 6. Distribution of overturned pine trees among particular classes of wind velocity

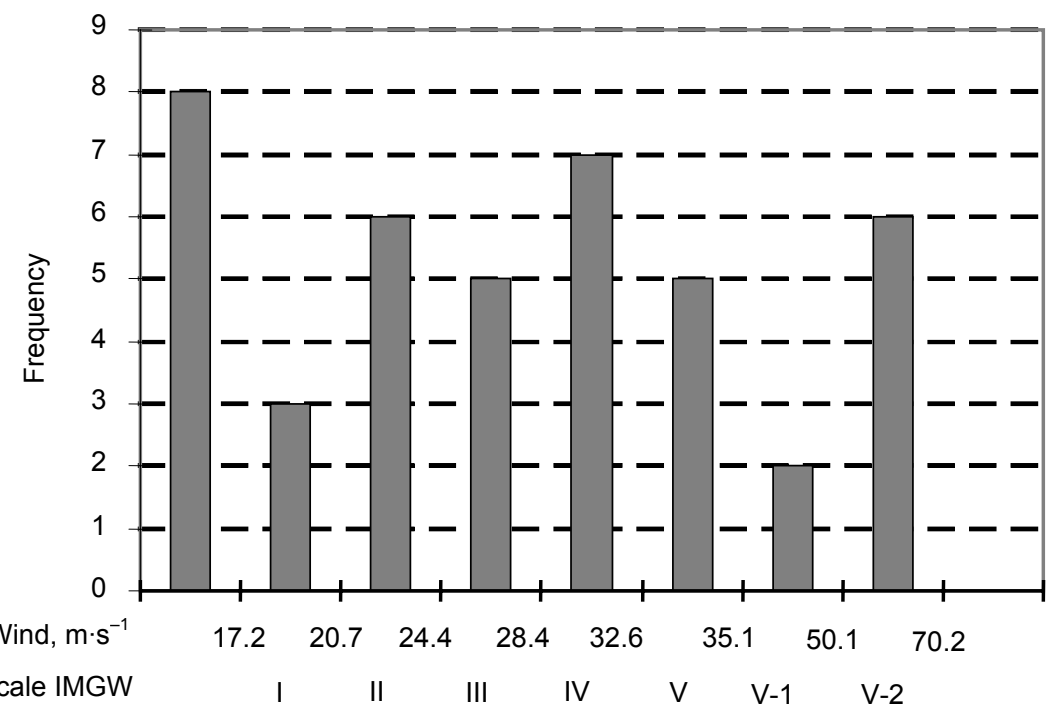

Fig. 7. Distribution of overturned black alder trees among particular classes of wind velocity

\section{SUMMARY}

IMGW as one of the main institutions in Poland dealing with weather phenomena proposed special scale of wind velocities. The scale was constructed based on the effects wind may cause and on the ranges of wind velocity. Using results 
from field experiments made in this study the classes of wind velocities were identified which might possibly cause significant losses in pine and alder tree stands.

One may predict substantial losses in pine tree stands already at the I class i.e. by winds blowing with a velocity of $20.7 \mathrm{~m} \cdot \mathrm{s}^{-1}$. At such wind velocities over $30 \%$ of tree stand would have been damaged. Further destruction could be expected by winds of the II and III class. Only $20 \%$ of tree stand is able to survive winds of such a force. Alder tree stands are definitely more resistant but performed studies showed that substratum is of utmost importance in that case. Since they grow on wet and loose substrata one may expect that part of these trees (20\% in this study) might be overturned already by winds below the I class of wind velocity. However, nearly $50 \%$ of trees will survive winds of the III class.

Unfortunately, long-term climatic forecasts say of the increasing number of extreme weather phenomena including strong winds. Hence, one may expect increasing losses. The only consolation is that wind velocity is lower inside the dense tree stand than above it. Trees growing at the edge of tree stand will, however, suffer from winds of high velocity.

\section{REFERENCES}

1. GIL W., Huragan znowu niszczy lasy, 2005. Poznajmy Las, 1.

2. HARTGE K.H., 1993. Ingenieurbiologie. Wurzelwerk Standsicherheit von Boschungen Hangen. Aachen, Sepia Verl.

3. KAŁUŻA T., WiERZBICKI J., 2006. Ocena momentu krytycznego podatności drzewostanów na ekstremalne czynniki hydro-meteorologiczne. Monografia. Warszawa, IMGW: 47-57.

4. LORENC H., 2008. Wiatr w Polsce, jako element zagrożenia: http://www.imgw.pl/wl/internet/zz/ wiedza/klimat/ klimat/archiwum/klimat 29012005.html

5. Proposed guidelines on the clearing and planting of trees in rivers, 1994. Tokyo, River Improvement and Management Division River Bureau Ministry of Construction: 155.

\section{STRESZCZENIE}

\section{Analiza stateczności drzewostanów wg klasyfikacji IMGW maksymalnych prędkości wiatru}

Słowa kluczowe: momenty wywracajace drzew, silne wiatry

Silne wiatry mogą powodować różnego typu zagrożenia i szkody, najbardziej narażone na zniszczenia są pojedyncze drzewa, ale również całe drzewostany. Ponieważ skutki działania wiatru zależą od jego prędkości, IMGW zaproponowało specjalnie opracowaną skalę do szacowania wielkości zniszczeń w zależności od prędkości wiatru. Problemy z opracowaniem takiej skali wynikają m.in. z faktu, że zdecydowanie trudniej jest przewidywać skutki, jakie wywoła określona prędkość 
wiatru na lądzie niż na morzu. To, czy dane drzewo pod wpływem wiatru zostanie połamane lub wyrwane z korzeniami, zależy od bardzo wielu czynników, takich jak: gatunek, wiek, rodzaj i wilgotność podłoża, pora roku itp. Proponowana klasyfikacja (IMGW lub stosowanie bezpośrednio skali Beauforta) jest zatem daleko idącym uśrednieniem możliwych do zaistnienia zdarzeń. Klasyfikacje takie są jednak konieczne ze względów prognostycznych, w tym wysyłania ostrzeżeń meteorologicznych.

Analizując stateczność na wywrócenie się drzewa, należy porównać ze sobą siłę zewnętrzną działającą na drzewo oraz jego odporność na wywrócenie (moment krytyczny). Wartości granicznego momentu wywracającego w przypadku drzew zależą zarówno od parametrów rośliny, jak i podłoża. W pracy przedstawiono wyniki badań nad oceną momentów krytycznych badanych drzewostanów sosnowych i czarnej olchy. Ocenę granicznego momentu wywracającego drzew przeprowadzono na dwóch obiektach doświadczalnych. Pierwszy zlokalizowany był na terenach zalewowych Warty w Częstochowie. Drugi natomiast na obrzeżach doliny rzeki Sama w pobliżu Obrzycka. Badania polowe polegały na pomiarze momentu siły potrzebnej do wyrwania drzewa. Pomiar siły wykonywano dynamometrem cyfrowym. Poprzez współpracę dynamometru z komputerem możliwe było precyzyjne notowanie narastania siły, aż do momentu wywrócenia drzewa. Źródłem siły był ciężki sprzęt budowlany wykorzystywany do zrębu lasu i prac drogowych. Wysokość zaczepienia liny powiększona o głębokość wykrotu stanowiła ramię siły służącej do oceny momentu krytycznego. Po zakończeniu wyrywania przystępowano do pomiaru pierśnicy, długości całkowitej drzewa, szerokości korony, szerokości bryły korzeniowej, głębokości wykrotu. Pobierano też próbki gruntu z wykrotu do analiz.

Wykorzystując wyniki pomiarów wartości momentów wywracających oraz wartości parametrów geometrycznych wywracanych drzew, oszacowano prędkości wiatru, które wywracałyby poszczególne drzewa. Do szacowania prędkości wiatru wykorzystano przekształcone równanie momentu sił wywracających drzewo na skutek działania wiatru. W dalszych analizach wyznaczone wartości prędkości wiatru odniesiono do klas maksymalnych prędkości wiatru zaproponowanych przez IMGW. Określono w ten sposób, w warunkach których klas prędkości wiatru mogą nastąpić znaczące straty w drzewostanach sosnowych i olchowych.

Received 08.12.2008

Reviewers:

Prof. Zbigniew Lechowicz

Prof. Jan Zajaczkowski 